\title{
Pengaruh Problem Based Learning dan Sains Teknologi Masyarakat Terhadap Motivasi Belajar
}

\author{
Awalina Barokah \\ PGSD Universitas Pelita Bangsa \\ Jl. Inspeksi Kalimalang No.9, Cibatu, Cikarang Sel., Kabupaten Bekasi, Jawa Barat \\ E-mail: awalina.barokah@pelitabangsa.ac.id
}

\begin{abstract}
Article Info
Abstract

Received Maret 2021

Accepted April 2021

Published April 2021

This study aims to reveal : (1) the effect of PBL on the motivation to learn; (2) the effect of STM on the motivation to learn; (3) differences on the motivation to learn between the group taught using PBL model and that taught using STM. This study was a quasi experiment with the

Keywords: nonequivalent comparison-group design. The data analysis used T-test and Univariate Analysis of Variance at the significance level of $5 \%$. The results

Problem-Based Learning,

Science Technology and are as follows: (1) PBL improved positively and significantly on the motivation to learn; (2) STM improved positively and significantly on the motivation to learn; (3) there is a significant and positive difference on the Society, Motivation to motivation to learn between the group taught using PBL model and that taught using STM model.
\end{abstract}

Abstrak : Penelitian ini bertujuan untuk mengetahui ; (1) pengaruh problem based learning (PBL) terhadap kemampuan motivasi belajar; (2) pengaruh sains teknologi masyarakat (STM) terhadap motivasi belajar ; (3) perbedaan motivasi belajar kelompok yang belajar menggunakan PBL dan kelompok yang belajar menggunakan STM. Penelitian ini merupakan penelitian eksperimen semu dengan desain nonequivalent comparison-group design. Analisis data menggunakan Uji-T and Univariate Analysis of Variance dengan taraf signifikansi 5\%. Hasil penelitian adalah sebagai berikut: (1) PBL berpengaruh positif dan siginifkan terhadap motivasi belajar ; (2) STM berpengaruh positif dan signifikan terhadap motivasi belajar; (3) terdapat perbedaan motivasi belajar yang signifikan dan positif kelompok yang belajar menggunakan PBL dan kelompok yang belajar menggunakan STM.

Kata Kunci: Problem-Based Learning, Sains Teknologi Masyarakat, Motivasi Belajar

C2021 Jurusan Ilmu Pendidikan, FKIP Universitas Lampung 


\section{PENDAHULUAN}

Salah satu faktor penentu keberhasilan belajar adalah motivasi siswa dalam belajar. Motivasi dijadikan sebagai pendorong dan pengarah dalam mencapai tujuan belajar. Siswa harus dibawa dalam situasi termotivasi agar tujuan pembelajaran dapat tercapai. Situasi belajar siswa dapat tumbuh dengan memberikan pembelajaran yang sesuai dengan kebutuhan siswa. Kebutuhan belajar tentunya selalu berubah seiring dengan perkembangan zaman.

Pembelajaran saat ini harus memfasilitasi siswa untuk mendapatkan kesempatan menemukan serangkaian konsep, prinsip atau hukum berupa kebiasaan berpikir dalam bentuk pemecahan masalah. Pembelajaran yang melibatkan siswa dalam suatu kegiatan berupa penyajian masalah dunia nyata akan memudahkan siswa mengaplikasikan pengetahuan yang didapatkan dalam kehidupan sehari-hari. Pembelajaran yang melibatkan siswa dalam suatu pemecahan masalahan di kehidupan sehari-harinya dapat mendorong siswa ke dalam keadaan termotivasi. Dalam hal ini pembelajaran yang dilakukan siswa bukan semata-mata karena nilai yang harus didapatkan setelah pembelajaran tetapi lebih kepada solusi yang didapatkan setelah pembelajaran, sehingga siswa dapat mengimplikasikan ilmu yang didapatkan melalui pembelajaran tersebut.

Pembelajaran melalui pemecahan masalah bukan hanya dibutuhkan siswa saat ini, tetapi juga pembelajaran yang di dalamnya mengaitkan peranan teknologi dan masyarakat dalam upaya untuk mengatasi berbagai permasalahan yang dapat diatasi dengan ilmu pengetahuan. Inovasi teknologi-teknologi yang dikaitkan dengan masyarakat dapat menumbuhkan kemauan siswa untuk belajar. Kemauan siswa untuk belajar tersebut akan membawa siswa ke dalam situasi termotivasi.

Untuk menunjang pembelajaran yang memotivasi siswa dan memfasilitasi siswa maka diperlukan model pembelajaran yang dapat mendorong siswa ke dalam situasi termotivasi. Model pembelajaran yang dapat menumbuhkan motivasi belajar tersebut yaitu model pembelajaran problem based learning (PBL) dan sains teknologi masyarakat (STM). Model problem based learning (PBL) merupakan model pembelajaran yang lebih menekankan pada 
pemecahan masalah. Siswa harus terlibat dalam pembelajaran yang didalamnya terdapat kegiatan berupa diskusi bermakna, menganalisis situasi yang berkaitan dengan permasalahan dunia nyata dan mempertimbangkan alternatif solusi yang harus dilakukan. Siswa juga bisa memilih permasalahan yang menarik untuk dipecahkan sehingga siswa termotivasi untuk terlibat dalam pemecahan masalah tersebut. Dengan memilih masalah dan mencari alternatif solusi dari berbagai permaslahan yang muncul dapat memotivasi siswa belajar.

Model pembelajaran sains teknologi masyarakat (STM) memfasilitasi siswa dalam menghubungkan sains, teknologi dan masyarakat. Teknologi sebagai hasil pengembangan dari konsep-konsep sains akan memenuhi kebutuhan masyarakat. Pembelajaran ini mendorong siswa untuk tanggap terhadap isu-isu yang berkembang di masyarakat, kemudian siswa akan menganalisis untuk mencari solusi yang harus dilakukan, dan siswa juga akan mengkomunikasikan serta mengaplikasikan solusi yang didapatkannya dalam kehidupan sehari-hari. Hal ini akan mendorong motivasi belajar.

Faktanya, pola pembelajaran di sekolah dasar kurang memberikan bekal kepada siswa dalam melibatkan siswa dalam pembelajaran, sehingga siswa kurang mempunyai dorongan atau motivasi dalam belajar. Proses pembelajaran kurang menyajikan pembelajaran yang memfasilitasi siswa mencapai tujuan pembelajaran. Ini menjadi salah satu kesulitan untuk membangkitkan motivasi belajar siswa.

Berdasarkan hasil observasi ditemukan bahwa motivasi belajar siswa masih cenderung rendah. Hal ini terlihat dari: (1) pada awal pembelajaran, siswa cenderung memiliki motivasi belajar yang cukup, namun semakin lama motivasi siswa semakin turun; (2) berdasarkan hasil observasi dari 51 siswa ada 50\% siswa yang cenderung ulet dan mampu menghadapi permasalahan dalam pembelajaran, hal ini terlihat ketika siswa diberikan soal yang menurutnya sulit, siswa memilih untuk tidak mengerjakan dan tidak ada upaya untuk bertanya pada guru atau temannya; (3) siswa lebih memilih untuk melihat hasil pekerjaan temannya dibandingkan mencoba untuk mengerjakan sendiri; dan (4) hanya ada beberapa siswa yang mampu mengungkapkan pendapatnya, itupun masih ragu-ragu. Berdasarkan observasi yang telah dilakukan maka siswa belum memiliki motivasi dalam pembelajaran 
Selain itu, hasil wawancara yang dilakukan dengan guru kelas diperoleh data informasi bahwa (1) guru merasa kesulitan membawa siswa untuk termotivasi dalam pembelajaran; (2) siswa hanya termotivasi apabila pembelajaran dilakukan di luar kelas; (3) siswa tidak berani mengeluarkan pendapat apalagi untuk mengeluarkan pendapat yang berbeda dari temantemannya. Dengan demikian, terkait dengan hasil wawancara dapat diidentifikasikan bahwa motivasi belajar siswa masih rendah.

Peneliti melakukan penelitian dengan mengujicobakan problem based learning (PBL) dan sains teknologi masyarakat (STM) pada pembelajaran. Hal ini dimaksudkan untuk mengetahui ada tidaknya perbedaan motivasi belajar dengan menggunakan pembelajaran problem-based learning dan sains teknologi masyarakat pada siswa.

\section{METODE}

\section{Jenis Penelitian}

Penelitian ini menggunakan pendekatan kuantitatif dengan jenis penelitian eksperimen semu dengan desain nonequivalent comparison-group design. Dalam desain ini terdapat dua kelompok yang dipilih secara acak dan diasumsikan kedua kelompok memiliki karakteristik yang sama (homogen).

\section{Populasi dan Sampel}

Populasi dalam penelitian ini adalah seluruh siswa kelas V SD Negeri Padokan 2 kecamatan Kasihan Kabupaten Bantul yang berjumlah 83 siswa dibagi tiga kelas menjadi kelas A yang berjumlah 23 siswa, kelas B yang berjumlah 28 siswa dan kelas C yang berjumlah 32 siswa. Sampel penelitian ini adalah siswa kelas VA dan kelas VB. Selanjutnya dua kelas tersebut dipilih secara acak untuk menentukan kelas mana yang diberi perlakuan dengan menerapkan problem based learning dan yang diberi perlakuan dengan sains teknologi masyarakat. Berdasarkan penentuan secara acak tersebut, maka siswa kelas VA mendapatkan pembelajaran dengan menggunakan sains teknologi masyarakat dan kelas VB mendapatkan pembelajaran dengan menggunakan problem based learning. 


\section{Teknik Pengumpulan Data}

Skala awal motivasi belajar diadakan pada kedua kelompok eksperimen. Kemudian dilakukan uji perbedaan untuk memperoleh kondisi awal yang sama. Pada akhir perlakuan dilihat perbedaan skala motivasi belajar yang didapatkan pada skala motivasi belajar awal dan skala motivasi belajar akhir di kelompok eksperimen. Hasil skala motivasi belajar diantara kedua kelompok terdapat perbedaan, maka akan diketahui pengaruh dari perlakuan yang diberikan.

Skala yang digunakan dalam penelitian ini yaitu skala motivasi belajar dengan menggunakan model skala Likert, di mana terdapat item favorable dan item unfavorable. Penelitian ini menggunakan skala motivasi belajar dengan empat alternatif jawaban, yaitu Selalu (SL), Sering (SR), Kadang-kadang (KD), dan Tidak Pernah (TP).

Teknik analisis data menggunakan Uji-T and Univariate Analysis of Variance dengan taraf signifikansi 5\%. Data yang digunakan adalah data yang didapatkan dari motivasi belajar siswa sebelum proses pembelajaran dan skala motivasi belajar setelah pembelajaran.

\section{Teknik Analisis Data}

Sebelum dilakukan uji hipotesis terlebih dahulu dilakukan uji asumsi prasyarat. Adapun uji asumsi yang dilakukan yaitu uji normalitas dan uji homogenitas. Uji normalitas univariate menggunakan uji kolmogorov-smirnov, sedangkan untuk uji homogenitas menggunakan uji Lavene. Setelah melakukan uji asumsi prasyarat baru dilakuan uji hipotesis. Hipotesis yang akan diuji adalah : (1) Problem based learning berpengaruh positif dan signifikan terhadap motivasi belajar siswa ; (2) Sains teknologi masyarakat berpengaruh positif dan signifikan terhadap motivasi belajar siswa; (3) Terdapat perbedaan yang signifikan dan positif motivasi belajar kelompok yang belajar menggunakan problem based learning (PBL) dan kelompok yang belajar menggunakan sains teknologi masyarakat (STM) pada siswa. Hipotesis satu dan dua diuji dengan uji-t. Hipotesis yang terakhir diuji dengan menggunakan uji Univariate Analysis of Variance. 


\section{HASTL}

Berdasarkan hasil analisis deskriptif yang digunakan untuk mendeskripsikan data skala motivasi belajar sebelum dan sesudah perlakuan. Adapun data motivasi belajar siswa tersaji dalam tabel 1.

Tabel 1. Deskripsi Data Motivasi Belajar

\begin{tabular}{ccc}
\hline Deskripsi & PBL & STM \\
\hline Pretest & 77,7857 & 77,6957 \\
Post-test & 90,00 & 81,6957 \\
\hline
\end{tabular}

Tabel 1 memberikan gambaran bahwa nilai rata-rata motivasi belajar setelah perlakuan dengan problem based learning mengalami perubahan. Selanjutnya hasil uji asumsi yang dilakukan sebelum melakukan uji hipotesis terhadap motivasi belajar baik untuk kelompok siswa yang belajar menggunakan model pembelajaran problem based learning maupun siswa yang belajar menggunakan model pembelajaran sains teknologi masyarakat. Adapun ringkasan hasil uji asumsi prasyarat yang berupa uji normalitas dan uji homogenitas univariate.

Dari output perhitungan data diperoleh signifikansi skala motivasi belajar untuk variabel motivasi belajar pada kelas yang belum menggunakan problem based learning sebesar 0,730. Adapun signifikansi skala motivasi belajar pada kelas yang sudah menggunakan problem based learning 0,517. Sedangkan dari output perhitungan data diperoleh signifikansi skala motivasi belajar untuk variabel motivasi belajar pada kelas yang belum menggunakan sains teknologi masyarakat sebesar 0,755. Adapun signifikansi skala motivasi belajar pada kelas yang sudah menggunakan sains teknologi masyarakat sebesar 0,511.

Dari hasil perhitungan tersebut diperoleh informasi bahwa nilai signifikansi kolmogorov-smirnov pada aspek kemampuan motivasi belajar baik pada pre-test dan post-test lebih besar dari 0,05 baik untuk kelompok yang menggunakan problem based learning, maupun sains teknologi masyarakat. Hal ini mengindikasikan bahwa asumsi normalitas univariat data terpenuhi.

Selanjutnya dilakukan uji homogenitas untuk mengetahui subjek penelitian berasal dari populasi yang homogen atau tidak. Dari output perhitungan data diperoleh nilai signifikansi motivasi belajar sebelum perlakuan sebesar 0,999 dan sesudah perlakuan sebesar 0,881. Berdasarkan hasil perhitungan tersebut diperoleh informasi bahwa nilai signifikansi uji 
lavene lebih besar 0,05 untuk kedua aspek. Hal ini mengindikasikan bahwa asumsi homogenitas terpenuhi untuk data motivasi belajar.

Hasil uji asumsi menunjukkan bahwa data post-test baik untuk kelompok problem based learning, dan sains teknologi masyarakat berdistribusi normal dan varians kedua kelompok juga homogen. Dengan demikian dapat dilakukan uji hipotesis. Adapun untuk menguji hipotesis pertama, maka dapat dilihat hasil analisis data motivasi belajar dalam pembelajaran problem based learning dalam tabel 2.

Tabel 2. Hasil Uji-T

Motivasi Belajar dengan Problem Based Learning

\begin{tabular}{cccc}
\hline Problem based learning & Mean & T-hitung & P \\
\hline Pre-test & 77,7857 & & \\
Post-test & 90,00 & 13,268 & 0,000 \\
\hline
\end{tabular}

Berdasarkan data dalam tabel 2, diperoleh rata-rata pre-test motivasi belajar menggunakan problem based learning sebesar 77,7857 dan post-test sebesar 90,00. Data tersebut menunjukkan bahwa rata-rata motivasi belajar pre-test dan post-test dengan problem based learning terdapat perubahan. Perubahan tersebut terlihat dari nilai rata-rata setelah perlakuan mengalami peningkatan. Ini menunjukkan bahwa adanya pengaruh problem based learning terhadap motivasi belajar siswa.

Selain itu, berdasarkan output perhitungan data juga diketahui $\mathrm{T}_{\text {hitung }}$ sebesar 13,268 dan $\mathrm{P}$ sebesar 0,000; $\mathrm{P}=0,000<0,05$; maka $\mathrm{H}_{0}$ dapat ditolak, sehingga dapat disimpulkan bahwa terdapat problem based learning berpengaruh signifikan dan positif terhadap motivasi belajar siswa. Dengan demikian hipotesis pertama yang menyatakan bahwa "problem based learning berpengaruh positif dan siginifkan terhadap motivasi belajar siswa" diterima.

Adapun untuk menguji hipotesis kedua, maka dapat dilihat hasil analisis data motivasi belajar dalam pembelajaran sains teknologi masyarakat dapat dilihat dalam tabel 3.

Tabel 3. Hasil Uji-T

Motivasi belajar dengan Sains Teknologi Masyarakat

\begin{tabular}{cccc}
\hline Sains Teknologi Masyarakat & Mean & T-hitung & P \\
\hline Pre-test & 77,6957 & & \\
Post-test & 81,6957 & 2,957 & 0,007 \\
\hline
\end{tabular}


Berdasarkan data dalam tabel 3, diperoleh rata-rata pre-test motivasi belajar menggunakan sains teknologi masyarakat sebesar 77,6957 dan post-test sebesar 81,6957. Data tersebut menunjukkan bahwa rata-rata motivasi belajar pre-test dan post-test dengan sains teknologi masyarakat terdapat perubahan. Perubahan tersebut terlihat dari nilai rata-rata setelah perlakuan mengalami peningkatan. Ini menunjukkan bahwa adanya pengaruh sains teknologi masyarakat terhadap motivasi belajar siswa.

Selain itu, berdasarkan output perhitungan data juga diketahui Thitung sebesar 2,957 dan $\mathrm{P}$ sebesar 0,007; $\mathrm{P}=0,007<0,05$; maka $\mathrm{H}_{0}$ dapat ditolak, sehingga dapat disimpulkan bahwa terdapat sains teknologi masyarakat berpengaruh signifikan dan positif terhadap motivasi belajar. Dengan demikian hipotesis kedua yang menyatakan bahwa "sains teknologi masyarakat berpengaruh positif dan siginifkan terhadap motivasi belajar" diterima.

Uji hipotesis ketiga dilakukan deng terlebih dahulu melakukan analisis data sebelum perlakuan dengan Univariate Analysis of Variance untuk melihat apakah kondisi awal untuk kedua kelompok sama. Berdasarkan hasil analisis data pre-test motivasi belajar diperoleh pada tabel 4 .

Tabel 4. Hasil Uji Univariate Analysis of Variance Pre-Test Motivasi Belajar

\begin{tabular}{ccccc}
\hline Kelas & Mean & F-hitung & P & R Square \\
\hline Problem based learning & 77,7857 & & & \\
Sains teknologi masyarakat & 77,6957 & 0,005 & 0,942 & 0,000 \\
\hline
\end{tabular}

Berdasarkan data dalam tabel 4, diperoleh rata-rata pre-test motivasi belajar siswa kelompok problem based learning sebesar 77,7857 dan kelompok sains teknologi masyarakat 77,6957. Nilai rata-rata ini menunjukkan bahwa motivasi belajar sebelum diberi perlakuan sama. Dari data diatas juga diperoleh

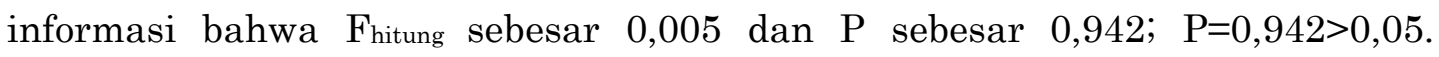
Berdasarkan hasil perhitungan tersebut, mengindikasikan bahwa tidak terdapat perbedaan terhadap motivasi belajar pada kedua kelompok yang digunakan dalam penelitian. Hal ini mengindikasikan bahwa $\mathrm{H}_{0}$ diterima, dengan kata lain kondisi awal motivasi belajar pada kedua kelompok sama.

Adapun untuk menguji hipotesis ketiga, maka dapat dilihat dalam hasil analisis data post-test motivasi belajar dapat dilihat dalam tabel 5 . 
Tabel 5. Hasil Uji Univariate Analysis of Variance Post-Test Motivasi Belajar

\begin{tabular}{ccccc}
\hline Kelas & Mean & F-hitung & P & R Square \\
\hline Problem based learning & 90,00 & & & \\
Sains teknologi masyarakat & 81,6957 & 24,315 & 0,000 & 0,332 \\
\hline
\end{tabular}

Berdasarkan data dalam tabel 5, diperoleh rata-rata post-test motivasi belajar kelompok problem based learning sebesar 90,00 dan kelompok sains teknologi masyarakat 81,6957 . Nilai rata-rata ini menunjukkan bahwa motivasi belajar siswa antara kelompok problem based learning dan sains teknologi masyarakat terdapat perbedaan. Perbedaan tersebut terlihat dari motivasi belajar kelompok problem based learning lebih tinggi dibandingkan kelompok sains teknologi masyarakat.

Berdasarkan output SPSS juga diketahui Fhitung sebesar 24,315 dan P sebesar 0,$000 ; \mathrm{P}=0,000<0,05 ;$ maka $\mathrm{H}_{0}$ ditolak, sehingga dapat disimpulkan bahwa terdapat perbedaan yang signifikan kemampuan motivasi belajar antara kelompok problem based learning dan sains teknologi masyarakat. Dengan demikian hipotesis kedua yang menyatakan bahwa "terdapat perbedaan yang signifikan dan positif motivasi belajar kelompok yang belajar menggunakan problem based learning (PBL) dan kelompok yang belajar menggunakan sains teknologi masyarakat (STM)” diterima.

Hasil uji $\mathrm{R}^{2}$ pada penelitian ini diperoleh nilai $\mathrm{R}^{2}$ sebesar 0,332 . Hal ini menunjukkan bahwa motivasi belajar dipengaruhi model pembelajaran problem based learning dan sains teknologi masyarakat sebesar 33,2\%, sedangkan sisanya $66,8 \%$ dipengaruhi faktor lain yang tidak termasuk dalam penelitian ini.

Hasil penelitian yang menunjukkan bahwa ada pengaruh problem based learning (PBL) terhadap motivasi belajar siswa. Hal ini dibuktikan dnegan nilai Thitung sebesar 13,268 dan $\mathrm{P}$ sebesar 0,000; $\mathrm{P}=0,000<0,05$; sehingga penelitian ini berhasil membuktikan hipotesis kedua yang menyatakan bahwa "problem based learning berpengaruh positif dan siginifkan terhadap motivasi belajar". Hasil penelitian juga menunjuukan bahwa motivasi belajar siswa dipengaruhi problem based learning. Hal ini dibuktikan dengan nilai rata-rata motivasi belajar pre-test 77,7857 dan post-test sebesar 90,00. 


\section{PEMBAHASAN}

Motivasi belajar merupakan suatu dorongan dan arah untuk mengubah perilaku dalam belajar sebagai upaya mencapai tujuan belajar. Pendapat yang sama dijelaskan oleh (Schunk 2012) "motivation is the process of instigating and sustaining goal directed behavior”. Seseorang yang merubah perilakunya dalam mencapai tujuan tertentu itulah yang disebut motivasi. Motivasi dijadikan sebagai dorongan yang memberi kekuatan bagi siswa untuk belajar. Dalam pembelajaran guru harus membawa siswa ke dalam keadaan termotivasi melalui pembelajaran yang melibatkan siswa dalam suatu kegiatan agar siswa tersebut dapat mencapai tujuan pembelajaran. Peran guru dalam mengembangkan motivasi belajar siswa adalah mengubah kelas kedalam situasi termotivasi. Hasil penelitian menunjukkan bahwa problem based learning memberikan pengaruh terhadap motivasi belajar siswa. Siswa akan terdorong dalam belajar ketika dia dihadapkan dalam sebuah permasalahan nyata.

Hasil penelitian yang menunjukkan bahwa ada pengaruh sains teknologi masyarakat (STM) terhadap motivasi belajar. Hal ini dibuktikan dengan nilai Thitung sebesar 2,957 dan $\mathrm{P}$ sebesar 0,$007 ; \mathrm{P}=0,000<0,05$; sehingga penelitian ini berhasil membuktikan hipotesis keempat yang menyatakan bahwa "sains teknologi masyarakat (STM) berpengaruh positif dan siginifkan terhadap kemampuan motivasi belajar". Hasil penelitian juga menunjukan bahwa kemampuan berpikir kritis dipengaruhi sains teknologi masyarakat. Hal ini dibuktikan dengan nilai rata-rata motivasi belajar pre-test 77,6957 dan posttest sebesar 81,6957. Motivasi merupakan suatu dorongan untuk melakukan aktivitas dalam mencapai tujuan. Pendapat yang sama dikemukakan (Korb 2012)“something that leads or influences a person to do something”. Yang dimaksudkan bahwa motivasi mempengaruhi atau menyebabkan seseorang untuk melakukan kegiatan. Hasil penelitian menunjukkan bahwa sains teknologi masyarakat berpengaruh terhadap motivasi belajar. Pendapat ini diperkuat oleh (Lester et al. 2006) yang menjelaskan kelebihan model sains teknologi masyarakat "science and technology concepts provide students with background knowledge that helps them develop the confidence and motivation to investigate and evaluate current issues, including personal matters, social concerns, and cultural perspectives". Sains teknologi masyarakat memfasilitiasi 
siswa untuk memiliki pengetahuan yang dapat membantu siswa meningkatkan rasa percaya diri dan mendorong siswa untuk melakukan penyelidikan serta mengevaluasi persoalan yang terjadi sekarang baik persoalan pribadi, sosial maupun terkait budaya. Hal ini akan mendorong siswa dalam belajar, sehingga memotivasi siswa dalam belajar.

Hasil penelitian yang menunjukkan bahwa ada perbedaan yang signifikan dan positif pada motivasi belajar antara kelompok problem based learning dan sains teknologi masyarakat. Hal ini dibuktikan dari nilai $\mathrm{F}_{\text {hitung }}$ sebesar 24,315 dan $\mathrm{P}=0,000$; oleh karena $\mathrm{P}=0,000<0,05$; sehingga penelitian ini berhasil membuktikan hipotesis keenam yang menyatakan bahwa "terdapat perbedaan yang signifikan dan positif motivasi belajar kelompok yang belajar menggunakan problem based learning (PBL) dan kelompok yang belajar menggunakan sains teknologi masyarakat (STM)". Hasil penelitian juga menunjukkan bahwa motivasi belajar antara kelompok problem based learning lebih tinggi daripada motivasi belajar kelompok sains teknologi masyarakat, ini dibuktikan dengan nilai rata-rata post-test motivasi belajar pada kelompok problem based learning sebesar 90,00 sedangkan rata-rata posttest motivasi belajar siswa pada kelompok sains teknologi masyarakat sebesar 81,6957.

(Feng, Fan, and Yang 2013) 'learning motivation refers to a student's willingness, need, desire and compulsion to participate in, and be successful in, the learning process". Motivasi belajar mengacu pada kemauan, kebutuhan, keinginan dan paksaan siswa untuk berpartisipasi dan sukses dalam proses pembelajaran. Motivasi belajar mengarahkan pada keinginan, keperluan, kemauan serta paksaan peserta didik untuk terlibat berhasil dalam proses pengajaran. Dalam pembelajaran guru harus membawa siswa ke dalam keadaan termotivasi melalui pembelajaran yang melibatkan siswa dalam suatu kegiatan agar siswa tersebut merasa sudah mencapai tujuan pembelajaran.

Pendapat ini senada dengan deskripsi (Saeed and Zyngier 2012) "in the classroom setting, student motivation refers to the degree to which a student puts effort into and focus on learning in order to achieve successful outcomes". Yang berarti dalam kelas, motivasi siswa mengacu pada sejauh mana siswa tersebut dapat melakukan usaha dan fokus pada pembelajaran agar tujuan pembelajaran tersebut dapat tercapai. Guru harus memfasilitasi siswa dalam 
meningkatkan motivasi belajar dikelas dengan model pembelajaran yang inovatif.

Motivasi belajar siswa pada kelompok yang belajar menggunakan problem based learning lebih tinggi dibandingkan dengan kelompok belajar yang menggunakan sains teknologi masyarakat. Problem based learning merupakan pembelajaran yang didalamnya terdapat penyajian masalah sehingga memfasilitasi siswa untuk terlibat dalam pembelajaran. Pembelajaran ini didalamnya terdapat berbagai aktivitas yang penyajian masalah dan penyelesaian masalah dalam kelompok.

Aktivitas penyajian masalah autentik, kegiatan penyelidikan atau investigasi, dan adanya diskusi dalam kelompok baik kelompok besar maupun kelompok kecil membuat siswa menjadi tekun, ulet dalam menghadapi kesulitan, mempunyai minat terhadap berbagai permasalahan yang muncul dan siswa lebih senang mencari dan memecahkan soal-soal. Dari penyajian masalah, siswa terdorong untuk menyelesaikan berbagai permasalahan yang muncul dalam kehidupan sehari-hari siswa. Dorongan ini yang akan membuat siswa terus termotivasi dalam belajar.

Temuan ini juga diperkuat oleh (Huang and Foreign 2012) yang berpendapat "the ultimate goals of PBL aimed to help learners elevate intrinsic motivation, build up thinking sills, develop higher level knowledge, and become self-guided learners who could cooperate and collaborate in groups". Problem based learning bertujuan untuk membantu siswa dalam meningkatkan motivasi intrinsik, membangun keterampilan berpikir, mengembangkan pengetahuan ke level yang lebih tinggi, dan menjadi pebelajar yang dibimbing untuk dapat bekerja sama dan berkolaborasi dalam kelompok.

Terdapat perbedaan motivasi belajar siswa yang belajar menggunakan problem based learning dan siswa yang belajar menggunakan sains teknologi masyarakat. Ini dikarenakan dalam beberapa aktivitias problem based learning lebih mendorong siswa kedalam situasi termotivasi. Misalnya kegiatan orientasi masalah, mendorong siswa mempunyai minat terhadap berbagai masalah dan mampu memecahkan soal-soal. Kemandirian siswa dan ketekunan siswa juga terpenuhi melalui aktivitas menyajikan hasil kerja. Dalam aktivitas menganalisis dan mengevaluasi solusi atas permasalahan dapat memfasilitasi siswa untuk lebih tekun dan ulet dalam menghadapi kesulitan. 
Motivasi belajar siswa pada kelas sains teknologi masyarakat lebih rendah jika dibandingkan dengan problem based learning dikarenakan tidak semua siswa tertarik dan mampu dalam penggunaan teknologi. Temuan ini tidak sejalan dengan pendapat Easton (2009) yang mendeskripsikan "technology is the application of knowledge (including scientific knowledge) to accomplish things we otherwise could not". Teknologi merupakan aplikasi dari pengetahuan (termasuk pengetahuan ilmiah) untuk memenuhi kebutuhan yang tidak bisa di lakukan. Bagi sebagian orang teknologi dapat mencukupi kebutuhan namun tidak semua orang dapat menggunakan teknologi.

Hal ini yang menyebabkan bahwa dalam pembelajaran model sains teknologi masyarakat, motivasi belajar siswa lebih rendah dikarenakan tidak semua siswa dapat menggunakan teknologi, sehingga siswa tidak mempunyai dorongan dalam belajar. Selain itu aktivitas dalam pembelajaran juga memerlukan keterampilan khusus sehingga siswa yang tidak mampu mengembangkan keterampilan tersebut cenderung tidak mempunyai dorongan atau motivasi dalam belajar. Pada temuan di penelitian ini, dorongan siswa dalam melakukan penyelidikan cenderung rendah dan tidak adanya ketertarikan siswa dalam melakukan penyelidikan yang melibatkan teknologi sederhana. Berdasarkan hasil tersebut dapat disimpulkan bahwa problem based learning dan sains teknologi masyarakat membawa pengaruh yang positif dan signifikan terhadap motivasi belajar.

\section{KESIMPULAN}

Berdasarkan hasil pengujian hipotesis dan pembahasan sehingga dapat disimpulkan bahwa problem based learning berpengaruh positif dan siginifkan terhadap motivasi belajar pada siswa, sains teknologi masyarakat berpengaruh positif dan siginifkan terhadap motivasi belajar siswa dan terdapat perbedaan yang signifikan dan positif terhadap motivasi belajar kelompok yang belajar menggunakan problem based learning (PBL) dan kelompok yang belajar menggunakan sains teknologi masyarakat (STM) pada siswa kelas V di SD

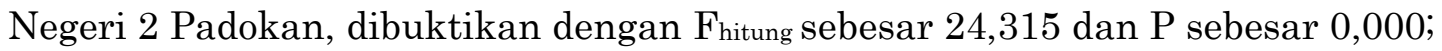
$\mathrm{P}=0,000<0,05$. Dengan perbedaan nilai rata-rata post-test motivasi belajar kelompok problem based learning sebesar 90,00 dengan kategori sangat tinggi dan kelompok sains teknologi masyarakat 81,6957 dengan kategori sangat tinggi. 


\section{DAFTAR PUSTAKA}

Easton, T. .. (2009). Taking Sides Clashing Views in Science, Technology,and Society. 8th ed. Boston: McGraw-Hill Higher Education.

Feng, Hsiang-Yung, Jin-Jun Fan \& Hui-Zhen Yang. (2013). "The Relationship of Learning Motivation and Achievement in EFL: Gender as an Intermediated Variable." Educational Research International 2(2):50-58.

Huang, Kuo-shu, \& Applied Foreign. (2012). "Applying Problem-Based Learning ( PBL ) in University English Translation Classes.” 7(1):121-27.

Korb, R. (2012). Motivating Defiant \& Disruptive Students to Learn. California: Corwin.

Lester, Benjamin T., Li Ma, Okhee Lee \& Julie Lambert. (2006). "Social Activism in Elementary Science Education: A Science, Technology, and Society Approach to Teach Global Warming." International Journal of Science Education 28(4):315-39. doi: 10.1080/09500690500240100.

Saeed, Sitwat \& David Zyngier. (2012). "How Motivation Influences Student Engagement: A Qualitative Case Study." Journal of Education and Learning 1(2):252-67. doi: 10.5539/jel.v1n2p252.

Schunk, D. .. (2012). Learning Theories an Educational Perspective. 6th ed. New York: Mc Graw-Hill. 